vary, not only among species, but also among individuals of the same species.

5. It is concluded that the inhibitors are not so highly specific as was previously believed. The variations in apparent turnover number are probably due to the presence in the tissue extracts of varying amounts of other substances competing with cholinesterase for the inhibitor.
Acknowledgement is made to the Chief Scientist, Ministry of Supply, for permission to publish this paper. [Crown Copyright reserved. Reproduced with the permission of the Controller of H.M. Stationery Office.]

I wish to express my indebtedness to $\mathrm{Mr}$ D. R. Davies for advice and encouragement. Thanks are also due to Dr B. C. Saunders for the sample of DCFP, to Mr S. Callaway for advice on statistical matters, and to Mr E. G. Harrold for technical assistance.

\title{
REFERENCES
}

Aldridge, W. N. (1950). Biochem. J. 46, 451.

Aldridge, W. N., Berry, W. K. \& Davies, D. R. (1949). Nature, Lond., 164, 925.

Augustinsson, C. B. \& Nachmansohn, D. (1949). J. biol. Chem. 179, 543.

Boursnell, J. C. \& Webb, E. C. (1949). Nature, Lond., 164, 875.

Chapman, N. B. \& Saunders, B. C. (1948). J. chem. Soc. p. 1010.

Davies, D. R. \& Smellie, R. M. S. (1949). Unpublished observations.

Easson, L. H. \& Stedman, E. (1936). Proc. roy. Soc. B, 121, 142.

Goldstein, A. (1944). J. gen. Physiol. 27, 529.

Jansen, E. F., Nutting, M-D. F. \& Balls, A. K. (1948). J. biol. Chem. 175, 975.

Jansen, E. F., Nutting, M-D. F. \& Balls, A. K. (1949). J. biol. Chem. 179, 201.
Mackworth, J. F. \& Webb, E. C. (1948). Biochem. J. 42, 91.

Mazur, A. (1946). J. biol. Chem. 164, 271.

Mazur, A. \& Bodansky, O. (1946). J. biol. Chem. 163, 261.

Mendel, B., Mundell, D. B. \& Rudney, H. (1943). Biochem.J. 37, 473.

Mounter, L. A. \& Whittaker, V. P. (1950). Biochem. J. 47, 525.

Nachmansohn, D., Rothenberg, M. A. \& Feld, E. (1948). J. biol. Chem. 174, 247.

Roepke, M. H. (1937). J. Pharmacol. 59, 264.

Rothenberg. M. A. \& Nachmansohn, D. (1947). J.biol. Chem. 168, 223.

Snedecor, G. W. (1946). Statistical Methods, p. 105, § 6.3. Iowa: State College Press.

Straus, O. H. \& Goldstein, A. (1943). J. gen. Physiol. 26, 559.

Strelitz, F. (1944). Biochem. J. 38, 86.

Webb, E. C. (1948). Biochem. J. 42, 96.

\section{The Preparation and Properties of $\beta$-Glucuronidase}

\section{CENTRIFUGAL FRACTIONATION OF WATER HOMOGENATES AND THE NATURE OF THE SEDIMENTABLE FRACTION}

\author{
By P. G. WALKER AND G. A. LEVVY \\ Rowett Research Institute, Bucksburn, Aberdeenshire
}

(Received 15 January 1951)

In the first paper in this series (Kerr \& Levvy, 1951) it was shown that buffering a water homogenate of mouse liver, kidney or uterus to a slightly acid $\mathrm{pH}$ led to fractionation of the $\beta$-glucuronidase activity on subsequent centrifuging at low speeds. Changes in the glucuronidase activity of these organs with the state of proliferation (Levvy, Kerr \& Campbell, 1948; Kerr, Campbell \& Levvy, 1949) were seen to be confined to the non-sedimentable fraction. In normal adult liver the sedimentable fraction accounted for nearly half the total glucuronidase activity in the buffered water homogenate. As described below, identical fractionation of mouseliver glucuronidase in untreated water homogenates can be achieved on the high-speed centrifuge. The partition of the enzyme has been correlated with microscopic observations in the homogenate, and methods for bringing the sedimentable fraction into solution have been studied.

\section{METHODS}

Preparation and fractionation of the enzyme. Mouse liver was ground with water for $1 \mathrm{~min}$. in a glass homogenizer. We have found Veridia precision bore glass tubing (Chance Bros. Ltd.) convenient for the manufacture of homogenizers. After dilution of the homogenate to a convenient volume, samples were taken for measurement of the total enzyme activity. Other samples were fractionated by one or both of the following methods: (a) After pH adjustment, the preparation was centrifuged on the M.S.E. (Measuring and Scientific Equipment Ltd., London, S.W. 1) Minor at $1500 \mathrm{~g}$ for $15 \mathrm{~min}$. If, as was usually the case, acetate buffer (pH $5 \cdot 2$ ) was used to adjust the $\mathrm{pH}$, the terms 'acetate-soluble' and 'acetate-insoluble' are sometimes used for the enzyme in the supernatant and sediment, respectively. (b) The preparation was centrifuged without $\mathrm{pH}$ adjustment on the M.S.E. Major with Superspeed Attachment. This was usually done at $20,000-25,000 \mathrm{~g}$ for $15 \mathrm{~min}$., yielding 'soluble' enzyme in the 'high-speed supernatant', and 'insoluble' enzyme in the sediment. TheSuperspeed centrifuge head was chilled before use. 
Tissue concentrations in preparations taken for centrifuging by either method varied from 2.5 to $10 \%(w / v)$. This factor was without influence on the distribution of enzyme activity between the two fractions.

In measuring the partition of enzyme activity, the figure for the sediment was found by difference from the figures for total and unsedimented enzyme. To determine the latter, a sample of the supernatant was withdrawn directly from the centrifuged preparation. For calculation, it was assumed that the unsedimented enzyme was uniformly distributed in the supernatant and debris. This assumption was found to be justified when the results were compared with those obtained by direct assay of both fractions after separation by method (a) (Table 1). For this purpose the supernatant was decanted and the sediment washed once on the centrifuge with one-tenth the original volume of fluid and then resuspended for assay with the aid of the glass homogenizer. The wash fluid was added to the supernatant fraction. The sediment separated by method (b) was seldom sufficiently well packed to permit complete decanting of the supernatant and thus direct measurement of the distribution of the enzyme. Nevertheless, even though separation was incomplete, the results for this method agreed with those for method (a) (Table 1) in showing that the sum of the figures for supernatant and sediment agreed with the figure for the total glucuronidase activity.

Enzyme assay. This was carried out as described by Kerr \& Levvy (1951). All enzyme preparations were diluted to a final volume of $20-40 \mathrm{ml} . / \mathrm{g}$. moist tissue, and $0.5 \mathrm{ml}$. was transferred to the tube containing phenolphthalein glucuronide and acetate buffer, $\mathrm{pH}$ 5·2. As noted by Kerr \& Levvy (1951), incomplete dilution of preparations containing insoluble enzyme may. lead to low results in the assay. Results are expressed as glucuronidase units (G.U.), where 1 G.U. liberates $1 \mu \mathrm{g}$. phenolphthalein from $0.00125 \mathrm{M}$-phenolphthalein glucuronide in $1 \mathrm{hr}$. at $37^{\circ}$ and $\mathrm{pH} 5 \cdot 2$.

Microscopy. Wet preparations were examined with the Cooke, Troughton and Simms Ltd. phase-contrast microscope, which is fitted with a phase plate giving $20 \%$ transmission and a retardation of $\lambda / 4$. Using an oil immersion lens, N.A. 1-3, and $\times 15$ compensating eyepieces, a final magnification of $\times 2000$ was attained with almost theoretical resolution $(0 \cdot 2 \mu$. : cf. Discombe, 1950).

\section{EXPERIMENTAL AND RESULTS}

\section{Identity of fractionation in buffered and unbuffered water homogenates}

In studying the fractionation of glucuronidase at ordinary centrifuge speeds, Kerr \& Levvy (1951) usually adjusted the $\mathrm{pH}$ to $5 \cdot 2$ with acetate or citrate buffer. Of these buffers, acetate was the more convenient to use for purposes of comparison with the fractionation of untreated homogenates on the highspeed centrifuge, since the partition of enzyme activity is less dependent on the $\mathrm{pH}$ and buffer concentration with acetate than with citrate.

Centrifuging an untreated homogenate of adult mouse liver at increasing speed caused a progressive fall in the activity of the supernatant (Fig. 1) and the sedimentation of an increasing proportion of that enzyme fraction which was acetate-insoluble, as was shown by subsequent fractionation of the various supernatants in acetate buffer. After centrifuging the unbuffered homogenate at $25,000 \mathrm{~g}$ for $15 \mathrm{~min}$., none of the residual supernatant activity was precipitated on buffering with acetate.

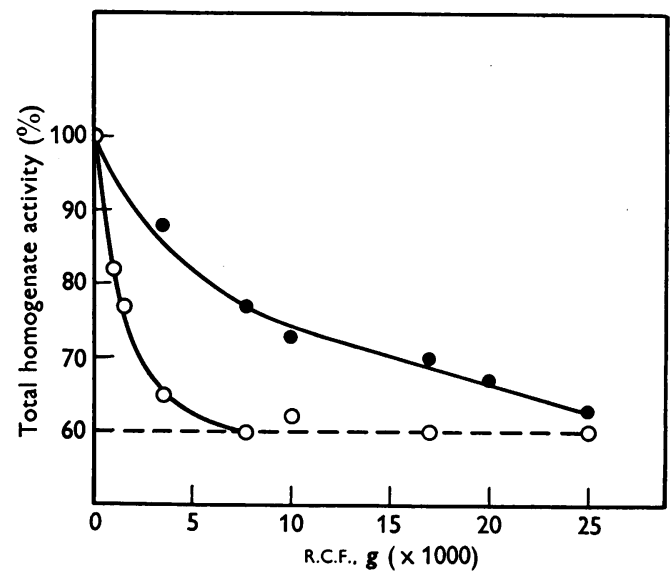

Fig. 1. Glucuronidase activity of the supernatant from an unbuffered water homogenate of adult mouse liver centrifuged at varying speeds for $15 \mathrm{~min}$. Total residual activities expressed as percentages of the initial homogenate activity. $\bigcirc$, untreated homogenate; $O$, homogenate made $0 \cdot 1 \mathrm{M}$ with respect to $\mathrm{NaCl}$; - - - acetate-soluble fraction in homogenate.

At moderate relative centrifugal force (R.C.F.) values, sedimentation of the insoluble enzyme in an unbuffered homogenate could be increased by lengthening the period of centrifuging. At 20,000 $25,000 \mathrm{~g}$ (the maximum attainable with our equipment), however, no further sedimentation occurred on centrifuging for 60 instead of $15 \mathrm{~min}$. The heating of the preparation during centrifuging had no effect on the overall enzyme activity, nor on the partition of the enzyme.

Table 2 gives average figures for the fractionation of adult and infant mouse-liver glucuronidase on the high-speed centrifuge $(20,000-25,000 \mathrm{~g}$ for $15 \mathrm{~min}$.), carried out in parallel with fractionation by acetate buffer. There was excellent agreement between the two methods of fractionation and, as noted by Kerr \& Levvy (1951), the fall in glucuronidase activity in passing from the infant to the adult tissue (Levvy et al. 1948) was confined to the soluble fraction.

In other experiments with infant and adult liver it was found that no material, active or inactive, could be brought down in the supernatant from buffered homogenates separated at $1500 \mathrm{~g}$ on subsequent centrifuging at $25,000 \mathrm{~g}$. Unbuffered highspeed supernatants, on the other hand, although devoid of acetate-insoluble enzyme, did contain inactive protein precipitable with acetate buffer, pH 5.2. 
Table 1. Comparison of alternative procedures for studying the fractionation of mouse-liver glucuronidase

(Homogenate of adult liver made $0.1 \mathrm{M}$ with respect to acetate buffer, $\mathrm{pH} 5 \cdot 2$, and centrifuged at $1500 \mathrm{~g}$ for $15 \mathrm{~min}$. In columns I, the washed sediment was assayed for insoluble enzyme activity. In columns II, the activity of this fraction was found by difference as described in the text.)

$\begin{array}{ccccccc}\text { Exp. } & \overbrace{\text { Supernatant }} & \text { Sediment } & & \overbrace{\text { Supernatant }}^{\text {Glucuronidase units/g. liver }} & \text { Sediment (calc.) } \\ \text { no. } & \text { Total } & 1740 & 1480 & 1780 & 1420 \\ 1 & 3200 & 1620 & 1520 & & 1620 & 1480 \\ 2 & 3100 & 1500 & 1200 & & 1520 & 1160 \\ 3 & 2680 & & \text { I } & \end{array}$

Table 2. Fractionation of mouse-liver glucuronidase on the high speed centrifuge, and on the low speed centrifuge after addition of acetate buffer, $\mathrm{pH} \mathbf{5 \cdot 2}$

(Values shown as mean \pm s.E. followed in parenthesis by the number of experiments.)

\begin{tabular}{|c|c|c|c|c|}
\hline \multirow{3}{*}{ Description } & \multicolumn{4}{|c|}{ Glucuronidase units/g. liver } \\
\hline & \multicolumn{2}{|c|}{ High-speed centrifuge } & \multicolumn{2}{|c|}{ Acetate treatment } \\
\hline & Soluble & Insoluble & Soluble & Insoluble \\
\hline $\begin{array}{l}\text { Normal adult } \\
\text { Infant (4-6 days old) }\end{array}$ & $\begin{array}{l}1707 \pm 46(12) \\
3003 \pm 108(7)\end{array}$ & $\begin{array}{l}1161 \pm 48(12) \\
1173 \pm 88(7)\end{array}$ & $\begin{array}{l}1625 \pm 37(12) \\
2943 \pm 120(7)\end{array}$ & $\begin{array}{l}1243 \pm 48(12) \\
1262 \pm 98(7)\end{array}$ \\
\hline
\end{tabular}

\section{Microscopic observations}

Under the phase microscope, a water homogenate of mouse liver was seen to be composed in the main of discrete spherical granules, ranging continuously in size from $5 \mu$. down to the limit of visibility. The smaller were by far the more numerous. A few intact or partially disintegrated cells, some nuclei and a variable number of fat globules were also present. Whilst we do not propose to discuss the fine structure of these components in detail, it should be noted that, with the exception of the fat globules, they all showed signs of pronounced osmotic swelling. Some of these effects have been observed by Zollinger (1948) under the phase microscope, by Opie (1949) in fixed stained preparations, and by Dalton, Kahler, Kelly, Lloyd \& Striebich (1949) under the electron microscope. As shown below, any arbitrary subdivision of the continuous range of granules visible under the phase microscope into such groups as 'mitochondrial' or 'large' on the one hand, and 'small' on the other hand, has no significance in the present connexion. In the following pages, therefore, the term granule is used for all cytoplasmic particles visible under the microscope, with the exception of the fat globules.

Centrifuging untreated homogenates of adult or infant mouse liver at increasing speeds caused a continuous fall in the number of granules in suspension, corresponding to the fall in supernatant glucuronidase activity illustrated in Fig. 1. Complete sedimentation of insoluble enzyme was not achieved until all but a very few of the smallest visible granules had been removed from the supernatant by centrifuging at $25,000 \mathrm{~g}$ for $15 \mathrm{~min}$.
Addition of acetate buffer, $\mathrm{pH} 5 \cdot 2$, to a water homogenate of mouse liver gave rise to an optically clear supernatant after centrifuging at $1500 \mathrm{~g}$ for $15 \mathrm{~min}$. Microscopically, the sediment consisted of large clumps of material formed by the agglutination of all the visible components of the homogenate, together with an amorphous protein precipitate. The precipitation of inactive soluble protein and the agglutination of the granules were observed separately by adding acetate buffer to an unbuffered high-speed supernatant, and to an aqueous suspension of the corresponding sediment, respectively.

It is clear that the sedimentable enzyme in a water homogenate of mouse liver is associated with granules of all sizes, and that the ease with which this enzyme fraction may be sedimented after the addition of acetate buffer is a result of the agglutination of the granules. The acetate-soluble enzyme, on the other hand, is in true solution, so far as we could judge microscopically and from its behaviour on the high-speed centrifuge.

\section{The effects of $\mathrm{pH}$ and electrolyte concentration}

Kerr \& Levvy (1951) found that the partition of the enzyme by acetate buffer at $1500 \mathrm{~g}$ was independent of the $\mathrm{pH}$ over the range $5 \cdot 0-5 \cdot 6(0 \cdot 1 \mathrm{M}$ buffer), and of the buffer concentration over the range $0.5-0.025 \mathrm{M}$ (pH 5.2). More extensive investigation of the effect of $\mathrm{pH}$ in $0 \cdot 1 \mathrm{M}$-acetate buffer has shown that the fractionation of the enzyme at $1500 \mathrm{~g}$ did not change between the $\mathrm{pH}$ limits 4 and 6 . Within this range, agglutination of the granules was pronounced. Incomplete sedimentation of the insoluble enzyme on the low-speed centrifuge outside the $\mathrm{pH}$ limits stated was correlated with incomplete 
agglutination of the granules. In such cases, subsequent high-speed centrifuging brought down the residual granules and associated insoluble enzyme.

At $\mathrm{pH} \mathrm{6 \cdot 8,} \mathrm{the} \mathrm{natural} \mathrm{pH}$ of the homogenate, the buffered preparation showed slight agglutination of the granules, and $20 \%$ of the activity sedimented at $1500 \mathrm{~g}$. This contrasted with a figure of $10 \%$ in the untreated homogenate. At this $\mathrm{pH}$ the acetate buffer acted purely as an electrolyte, since adding an equivalent concentration of sodium chloride produced the same effect. The action of this electrolyte is shown in Fig. 1. Making an unbuffered water homogenate $0.1 \mathrm{M}$ with respect to sodium chloride led to much easier sedimentation of the granules and associated glucuronidase activity.

With citrate, as opposed to acetate, buffer, Kerr \& Levvy (1951) found the upper pH limit for complete sedimentation of the insoluble enzyme at $1500 \mathrm{~g}$ to be 5.2. Microscopic studies have shown that above this $\mathrm{pH}$ in citrate buffer $(0.033 \mathrm{M})$ agglutination of the granules was incomplete.

In an unbuffered homogenate, $\mathrm{pH}$ adjustment to 5.0 with hydrochloric or acetic acid gave the usual fractionation of the liver enzyme at $1500 \mathrm{~g}$. At slightly higher $\mathrm{pH}$ values, however, the use of acid alone led not only to agglutination of the granules, but also to precipitation of part of the soluble enzyme. This can be seen from Table 3 by comparing by the electrolyte concentration. On repeating the experiments of Kerr \& Levvy (1951) we have formed the impression that a concentration of $0.025 \mathrm{M}$ acetate is barely high enough to ensure that the soluble enzyme is always kept entirely in solution at pH 5.2.

In other experiments it was found that part of the activity in preparations containing only soluble enzyme (high-speed supernatants) could be precipitated by adding acid. The optimum again appeared to be at $\mathrm{pH} \mathbf{5 \cdot 5}$, at which a quarter to a third of the enzyme sedimented. Centrifuging at 25,000 instead of $1500 \mathrm{~g}$ did not increase the amount of enzyme precipitated, nor did prolonged dialysis of the preparation prior to acidification.

Precipitation of soluble glucuronidase by acid was readily reversed by warming the preparation. After $15 \mathrm{~min}$. at $37^{\circ}$, only the granular enzyme sedimented from liver homogenates adjusted to $\mathrm{pH} 5.5$ with hydrochloric or acetic acid. The question of precipitation of soluble enzyme does not arise in other sections of this paper.

\section{Measures bringing the granular enzyme into solution}

Incubation at $37^{\circ}$. Kerr \& Levvy (1951) showed

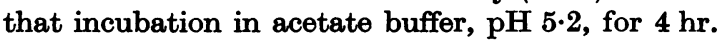
converted the granular enzyme into a soluble form. This change did not occur in citrate buffer at the

\section{Table 3. Precipitation of the soluble enzyme by acid}

(The $\mathrm{pH}$ of the adult liver homogenate was adjusted by the method shown. After centrifuging at $1500 \mathrm{~g}$ for $15 \mathrm{~min}$., assays were done at $\mathrm{pH} 5 \cdot 2$ in acetate buffer, and the results are expressed as percentages of the initial homogenate activity.)

\begin{tabular}{|c|c|c|c|c|c|}
\hline \multirow[b]{2}{*}{$\begin{array}{c}\mathrm{pH} \text { of } \\
\text { fractionation }\end{array}$} & \multicolumn{4}{|c|}{ Residual supernatant activity (\%) } & \multirow[b]{2}{*}{ Agglutination* } \\
\hline & $\begin{array}{l}0.1 \text { m-Acetate } \\
\text { buffer }\end{array}$ & $\mathrm{HCl}$ & $\begin{array}{l}\text { Acetic } \\
\text { acid }\end{array}$ & $0 \cdot 1 \mathrm{~m}-\mathrm{NaCl}+\mathrm{HCl}$ & \\
\hline $\begin{array}{l}\mathbf{4} \cdot 6 \\
5 \cdot 0 \\
5 \cdot 3 \\
5 \cdot 5 \\
5 \cdot 8 \\
6 \cdot 1\end{array}$ & $\begin{array}{l}\mathbf{5 9} \\
\mathbf{5 8} \\
\mathbf{5 7} \\
\mathbf{5 7} \\
\mathbf{5 8} \\
\mathbf{6 4}\end{array}$ & $\begin{array}{l}\mathbf{6 0} \\
\mathbf{5 7} \\
\mathbf{4 9} \\
\mathbf{4 3} \\
\mathbf{5 2} \\
\mathbf{6 4}\end{array}$ & $\begin{array}{l}\mathbf{5 7} \\
\mathbf{5 4} \\
\mathbf{4 7} \\
\mathbf{4 1} \\
\mathbf{5 6} \\
\mathbf{6 7}\end{array}$ & $\begin{array}{l}\mathbf{5 7} \\
\mathbf{5 5} \\
\mathbf{5 5} \\
\mathbf{5 5} \\
\mathbf{5 5} \\
\mathbf{6 0}\end{array}$ & $\begin{array}{l}++++ \\
++++ \\
++++ \\
++++ \\
++++ \\
++\end{array}$ \\
\hline
\end{tabular}

figures for the activity in the supernatant from an acid-adjusted homogenate with the corresponding figures for a buffered homogenate. Sedimentation of enzyme activity over and above that associated with the granules was at an optimum at pH 5.5. About a quarter of the soluble enzyme was precipitated by acid at this $\mathrm{pH}$. Addition of $0 \cdot 1 \mathrm{~m}$-sodium chloride to the homogenate prevented the precipitation of soluble enzyme, and acidifying then gave rise to the usual distribution of the enzyme up to the $\mathrm{pH}$ limit for complete agglutination. It would appear that the partition of glucuronidase activity in centrifuged liver homogenates buffered with acetate is not entirely a question of $\mathrm{pH}$, but is in part determined same $\mathrm{pH}$. It has now been found that conversion of granular into soluble enzyme does not occur in unbuffered homogenates after incubation for $24 \mathrm{hr}$. at the natural $\mathrm{pH}(6 \cdot 8)$, nor after $\mathrm{pH}$ adjustment to $5 \cdot 2$ with hydrochloric or acetic acid and incubation for $6 \mathrm{hr}$. There was no fall in the total activity of the incubated preparations in these experiments.

The complete conversion of granular enzyme into soluble enzyme after $4 \mathrm{hr}$. at $37^{\circ}$ and $\mathrm{pH} 5.2$ in acetate buffer has been confirmed with the highspeed centrifuge. Inspection of the incubated preparations under the microscope revealed no dispersion of the agglutinated granules and surprisingly little change in their general appearance. 
Acetate would thus appear to have extracted the enzyme from the granules.

The tissue disintegrator. Shaking a homogenate of mouse liver with Ballotini, Grade 12 (Chance Bros. Ltd.) in the Mickle Tissue Disintegrator (Mickle, 1948) for $30 \mathrm{~min}$. caused almost complete conversion of the granular enzyme into a soluble form, without appreciable inactivation. At the end of this treatment all the components of the homogenate were seen to have undergone disintegration, with complete loss of structure. On the high-speed centrifuge, part of the amorphous debris sedimented and part moved centripetally, leaving a clear intermediate layer; acetate buffer, $\mathrm{pH} 5 \cdot 2$, caused agglutination and ready sedimentation of the debris, leaving $94 \%$ of the enzyme activity in solution. Prior treatment of a homogenate with acetate buffer did not lessen the disruption of the granules and the release of enzyme to the solution on subsequent treatment in the disintegrator.

Freezing and thawing. Table 4 shows that repeated freezing in a mixture of solid carbon dioxide and acetone, and thawing at $37^{\circ}$, caused release of

\section{Table 4. Release of glucuronidase activity from the granules by repeated freezing and thawing}

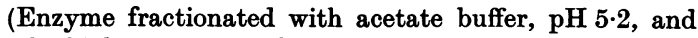
on the high-speed centrifuge.)

$\begin{array}{cccc}\begin{array}{c}\text { No. of } \\ \text { freezings } \\ \begin{array}{c}\text { and } \\ \text { thawings }\end{array}\end{array} & \begin{array}{c}\text { Total in } \\ \text { homogenate }\end{array} & \begin{array}{c}\text { Acetate- } \\ \text { soluble } \\ \text { enzyme }\end{array} & \begin{array}{c}\text { High-speed } \\ \text { supernatant }\end{array} \\ 0 & 3100 & 1680 & 1700 \\ 1 & - & 2100 & - \\ 4 & - & 2300 & - \\ 8 & 3100 & 2600 & 2600\end{array}$

glucuronidase activity from the granules in a liver homogenate to the solution. From microscopic observations, this treatment appeared to result in disruption of the granules.
Fishman, Springer \& Brunetti (1948), in studying the glucuronidase activity of white blood cells, used this method and found that 'the disruption of the cell membranes by water laking did not release as much enzymic activity as appeared in the lysate after the intermittent freezing-thawing procedure'. It appears possible from this that part of the enzyme in the white blood cell, as in the liver cell, is closely associated with cytoplasmic particles, but the original paper does not give sufficient experimental detail to permit any conclusion on this point.

Treatment with acetone. Homogenizing in acetone converted a large part of the granular enzyme into the water-soluble form. This is illustrated in Table 5. In Exp. 1, part of the liver was homogenized in acetone (about $5 \mathrm{ml} . / 0.5 \mathrm{~g}$. tissue) and centrifuged. The acetone was poured off and the last traces removed by blowing air into the centrifuge tube. When the dry powder was resuspended by homogenizing in water, $85 \%$ of the total glucuronidase activity was in the soluble fraction. The corresponding figure for another piece of the same liver homogenized directly in water was $60 \%$. Exp. 1 also shows that the treatment of liver with acetone resulted in a $6 \%$ drop in overall activity, whether through enzyme inactivation or a loss to the acetone layer it was impossible to decide. Microscopic examination of the acetone powder after resuspension in water showed that the majority of the granules had disintegrated. The remainder were shrunken, opaque and irregular in outline.

In Exp. 2, in Table 5, the liver was homogenized in water and the homogenate divided into two portions. Both samples were made $0 \cdot 1 \mathrm{M}$ with respect to acetate buffer, $\mathrm{pH} 5 \cdot 2$, and centrifuged. The acetate-insoluble material was washed with $0 \cdot 1 \mathrm{~m}$-buffer, and rehomogenized in water and acetone respectively. The acetone homogenate was treated as above, and $79 \%$ of the granular enzyme was finally obtained in a water-soluble form. From the control it could be seen that rehomogenizing the acetate-precipitated material in water converted

Table 5. The effect of acetone on the distribution of glucuronidase activity in adult mouse liver

(The dry powder obtained from the acetone-treated tissue or tissue preparation was resuspended in the aqueous medium shown prior to fractionation with acetate buffer or on the high-speed centrifuge.)

$\begin{array}{ccc}\begin{array}{c}\text { Exp. } \\ \text { no. }\end{array} & \text { Starting material } & \begin{array}{c}\text { Homogenizing } \\ \text { fluid }\end{array} \\ 1 & \text { Fresh liver } & \begin{array}{l}\text { Water } \\ \text { Acetone }\end{array} \\ & \text { Precipitate of acetate- } & \begin{array}{l}\text { Water } \\ \text { Acetone }\end{array} \\ 2 & \text { insoluble material } & \begin{array}{l}\text { Acetone } \\ \text { Acetone } \\ \text { Acetone }\end{array} \\ 3 & \text { Fresh liver } & \end{array}$

Suspension fluid for fractionation

Water

Water $0 \cdot 1 \mathrm{~m}-\mathrm{NaCl}$ Acetate buffer
Glucuronidase units/g. liver

$\begin{array}{ccc}\text { Total } & \begin{array}{c}\text { Acetate- } \\ \text { soluble } \\ \text { enzyme }\end{array} & \begin{array}{c}\text { High-speed } \\ \text { supernatant }\end{array} \\ 2880 & 1720 & - \\ 2720 & 2320 & 2320 \\ 1720 & 380 & - \\ 1680 & 1320 & 1350 \\ 2800 & 2300 & 2350 \\ 2800 & 1960 & - \\ 2800 & 1680 & -\end{array}$


$22 \%$ of the granular enzyme into the soluble form. The loss in enzyme activity resulting from the acetone treatment of the acetate-precipitated material was only $2 \%$.

In the third experiment in Table 5, the acetone powder from whole liver was rehomogenized in various aqueous media. In water, as before, more than $80 \%$ of the enzyme activity was found in the soluble fraction. The use of $0.1 \mathrm{~m}$-acetate buffer, pH 5.2, as suspension fluid, however, resulted in a similar partition of the activity to that seen in a water homogenate of fresh liver (cf. Table 2). The use of $0.1 \mathrm{M}$-sodium chloride at this stage resulted in a distribution of the enzyme which was intermediate in character between those obtained with water and with acetate buffer. It would appear from this experiment that agglutination of the granules during the resuspension of the acetone powder in an aqueous medium prevents the escape of their activity to the solution.

Acetone has been used in the large-scale preparation of glucuronidase from ox spleen (Fishman, 1939; Graham, 1946). Fishman (1939) precipitated the enzyme from an aqueous extract of the minced tissue with acetone, but Graham (1946) found that he obtained a greater final yield of the enzyme by treating the tissue mince directly with acetone and extracting the dry powder with water. It seems possible that the better yield in Graham's procedure was due as much to the conversion of granular enzyme into a water-soluble form as to the avoidance of losses originally suggested.

Treatment with surface-active agents. In view of their well known cytolytic actions (see, for example, Glassman, 1950), the effect of surface-active agents on the granules in water homogenates of mouse liver were studied. The ionic surface-active agents, in addition to their cytolytic properties, combine with proteins in general (Putnam, 1948). Depending upon the conditions, this reaction may result in precipitation, denaturation or catalysed hydrolysis of the protein, and enzymes may lose their activities.

Teepol XL (British Drug Houses Ltd.), a typical anionic surface-active agent, is a mixture of sodium salts of secondary alkyl sulphates, containing from eight to seventeen carbon atoms, and with an average mol.wt. of 304 (Shell Chemicals Ltd., private communication). This substance was added as a neutral solution to homogenates in which the final tissue concentration was $2.5 \%(w / v)$, and the preparations were fractionated, either on the highspeed centrifuge or by treatment with acetate buffer, as rapidly as possible (in less than $30 \mathrm{~min}$.). Assay followed immediately. As can be seen from Table 6, low concentrations of Teepol caused an increase in the proportion of the enzyme activity which was soluble. Almost all the enzyme was soluble in $0.5 \%$ (w/v) Teepol, at which concentration most of the particulate tissue material was no longer visible under the microscope. Remaining granules showed greatly reduced contrast. This concentration of Teepol also caused a slight increase in the total homogenate activity, due no doubt to the greater dispersion of the enzyme (cf. Kerr \& Levvy, 1951). Release of the granular enzyme to the solution by Teepol depended not only on the concentration, but also on the period of contact. Thus, with a Teepol concentration of $0.05 \%(w / v)$, Table 6 shows that $77 \%$ of the total enzyme activity was in solution. The corresponding figure, when fractionation was delayed by $2 \mathrm{hr}$. after adding the surface-active agent to the homogenate, was $97 \%$.

\section{Table 6. The action of surface-active agents on water homogenates of adult mouse liver}

(Surface-active agent added in concentrations shown to samples of a homogenate in which the final tissue concentration was $2.5 \%$. Enzyme fractionated as quickly as possible with acetate buffer, $\mathrm{pH} 5 \cdot 2$, and on the high-speed centrifuge. All figures obtained with the same liver preparation.)

\begin{tabular}{|c|c|c|c|}
\hline \multirow{2}{*}{$\begin{array}{l}\text { Concentration of } \\
\text { surface-active } \\
\text { agent* } \\
(\% \mathbf{w} / \mathbf{v})\end{array}$} & \multicolumn{3}{|c|}{ Glucuronidase units/g. liver } \\
\hline & $\begin{array}{c}\text { Total in } \\
\text { homogenate }\end{array}$ & $\begin{array}{l}\text { Acetate- } \\
\text { soluble } \\
\text { enzyme }\end{array}$ & $\begin{array}{l}\text { High-speed } \\
\text { supernatant }\end{array}$ \\
\hline Control & 2830 & 1710 & 1760 \\
\hline \multicolumn{4}{|l|}{ Teepol XL } \\
\hline $\begin{array}{l}0 \cdot 05 \\
0.15 \\
0.50 \\
1 \cdot 00 \\
1 \cdot 25 \\
1 \cdot 50 \\
2 \cdot 00\end{array}$ & $\begin{array}{r}2800 \\
2880 \\
2960 \\
2640 \\
720 \\
120 \\
0\end{array}$ & $\begin{array}{r}2160 \\
2560 \\
2800 \\
480 \\
160 \\
0 \\
0\end{array}$ & $\begin{array}{r}\overline{2640} \\
2800 \\
2160 \\
-\dagger \\
-\dagger\end{array}$ \\
\hline \multicolumn{4}{|l|}{ Triton X-100 } \\
\hline $\begin{array}{l}0 \cdot 01 \\
0 \cdot 02 \\
0 \cdot 04 \\
0 \cdot 12 \\
0 \cdot 25 \\
0 \cdot 50 \\
2 \cdot 00\end{array}$ & $\begin{array}{l}2960 \\
2960 \\
3040 \\
3040 \\
3040 \\
2960 \\
2880\end{array}$ & $\begin{array}{l}2000 \\
2320 \\
2720 \\
3040 \\
3120 \\
2960 \\
2960\end{array}$ & $\begin{array}{l}\overline{2240} \\
\overline{3040} \\
\overline{3040} \\
-\end{array}$ \\
\hline \multicolumn{4}{|l|}{ Triton A-20 } \\
\hline $\begin{array}{l}0 \cdot 10 \\
0 \cdot 50 \\
1 \cdot 00 \\
2 \cdot 00\end{array}$ & $\begin{array}{l}2880 \\
2880 \\
2880 \\
2880\end{array}$ & $\begin{array}{l}1840 \\
1840 \\
1920 \\
1760\end{array}$ & $\begin{array}{l}1920 \\
1920 \\
-\end{array}$ \\
\hline
\end{tabular}

* These concentrations underwent an eightfold dilution when the enzyme was transferred to the assay tubes.

$\dagger$ In other experiments with this Teepol concentration, figures for the activity in the high-speed supernatant were intermediate between those for total homogenate and acetatesoluble enzyme.

At Teepol concentrations of $1 \%(w / v)$ and more, inhibition of glucuronidase became evident. This effect was more marked in the acetate-soluble enzyme preparation than in the high-speed supernatant, and in both than in the unfractionated 
homogenate; that is inhibition was most pronounced when the protein content of the preparation was least. Inhibition of glucuronidase by Teepol and the protective effect of inactive protein is dealt with more fully in the next section.

Glassman (1950) has shown that certain non-ionic surface-active agents are non-haemolytic. Two of the non-ionic agents he studied, the non-haemolytic Triton A-20 and the haemolytic Triton X-100 (formerly labelled Triton N-100 and listed thus in Glassman's paper), were obtained from the Rohm and Haas Company, Philadelphia. Experiments similar to those carried out with Teepol showed that the actions of the two Triton samples on the liver granules paralleled their haemolytic properties (Table 6). Triton A-20 had no effect, whatsoever, whilst Triton X-100 in a concentration of $0.12 \%$ $(w / v)$ caused complete solution of the granular enzyme and the disappearance of visible particles from the homogenate. In the lower concentrations, the effect of Triton X-100 depended upon the period of contact. When fractionation was delayed by $2 \mathrm{hr}$. the soluble enzyme fraction in a homogenate containing $0.02 \%$ Triton X-100 rose from 78 to $84 \%$. Greater overall homogenate activity due to dispersion of the enzyme was also seen with this agent. Since the non-ionic surface-active agents do not react with proteins in general, it was not surprising to find that neither Triton X-100 nor Triton A-20 caused any appreciable fall in glucuronidase activity in the concentrations studied.

Kerr \& Levvy (1951) obtained false low results for the total glucuronidase activity of mouse-liver homogenates when the assay was carried out at too high a tissue concentration. The true activity was displayed at all tissue concentrations after complete conversion of the enzyme into a soluble form by incubating in acetate buffer. The slight activation of glucuronidase in liver homogenates sometimes observed with the surface-active agents, Teepol XL and Triton $X-100$, probably indicated greater dispersion of the enzyme than could be achieved by dilution alone (cf. 'Enzyme assay').

\section{Inhibition of glucuronidase by Teepol XL}

The inhibition of mouse-liver glucuronidase by Teepol XL noted above (Table 6) was further investigated in experiments in which changes in the partition of the enzyme were ignored. The first series of experiments dealt with the variation in inhibition with Teepol concentration and with the amount of inactive protein present (Fig. 2). The enzyme preparation consisted of a water homogenate of adult mouse liver in which the tissue concentration was $3.3 \%(w / v)$, or of the supernatant obtained by fractionating the homogenate in acetate buffer. For assay, the incubation mixture contained $0.5 \mathrm{ml}$. enzyme, $0.5 \mathrm{ml}$. substrate solution, and $3 \mathrm{ml}$.
$0 \cdot 1$ M-acetate buffer (pH 5.2) to which the Teepol was added. In some experiments, $0.25 \mathrm{ml}$. buffer was replaced by the same volume of boiled homogenate. The liberation of phenolphthalein after $1 \mathrm{hr}$. at $37^{\circ}$ in presence of Teepol was compared with that seen in its absence.

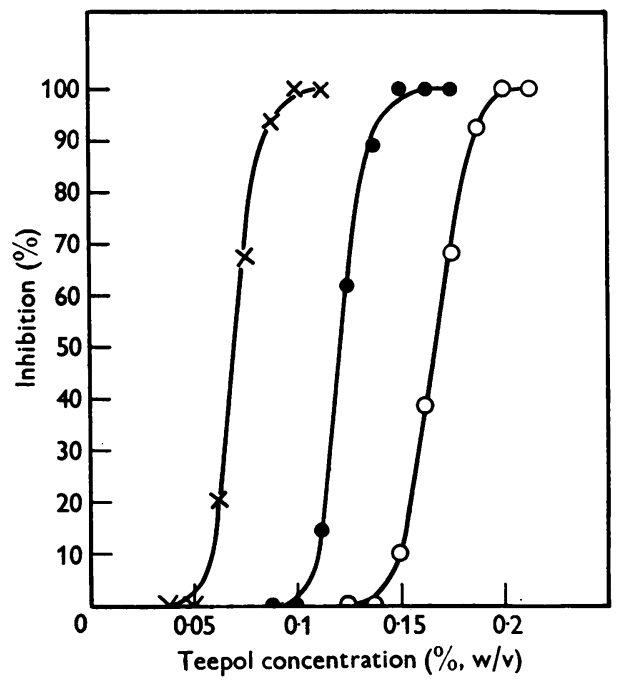

Fig. 2. Inhibition of glucuronidase by Teepol XL and protection by inactive protein. Substrate, 0.00125 M-phenolphthalein glucuronide in $0 \cdot 1 \mathrm{~m}$-acetate buffer, pH 5.2. Teepol added to assay tubes in concentrations shown. $\mathrm{O}-\mathrm{O}$, water homogenate of mouseliver; $x-\times$, acetatesoluble enzyme separated from above; -0 , acetatesoluble enzyme plus inactive protein.

Inhibition of glucuronidase occurred at much lower Teepol concentrations in the preparation of acetate-soluble enzyme than in the entire homogenate. The former preparation contained much less inactive protein than the latter (see above). Addition of inactive protein (boiled homogenate) to the acetate-soluble enzyme protected against concentrations of Teepol which otherwise were completely inhibitory. Rabinovitz \& Boyer (1950) used inactive protein to protect succinic oxidase against inhibition by sodium dodecyl sulphate. Different livers varied slightly in the degree of inhibition of glucuronidase produced by Teepol under fixed conditions. This was no doubt due to variations in the protein content of the wet tissue.

Inhibition of glucuronidase by Teepol XL was non-competitive. This was shown by the fact that the percentage inhibition of the hydrolysis of phenolphthalein glucuronide by acetate-soluble mouse liver glucuronidase in the presence of $0.06 \%$ $(w / v)$ Teepol did not vary over a range of substrate concentrations, the lowest of which $(0.0003 \mathrm{M})$ did not completely saturate the enzyme, whilst the highest $(0.005 \mathrm{M})$ was itself inhibitory. 
Delay in adding inactive protein made it progressively less effective in reversing inhibition by Teepol. This is shown in Fig. 3. The enzyme preparation was the supernatant from a $3 \cdot 3 \%(w / v)$ homogenate fractionated with acetate buffer. After varying periods of contact with the enzyme at room temperature, the action of the surface-active agent was arrested by transferring the preparation to assay tubes containing excess inactive protein $(0.25 \mathrm{ml}$. boiled homogenate). The rate at which

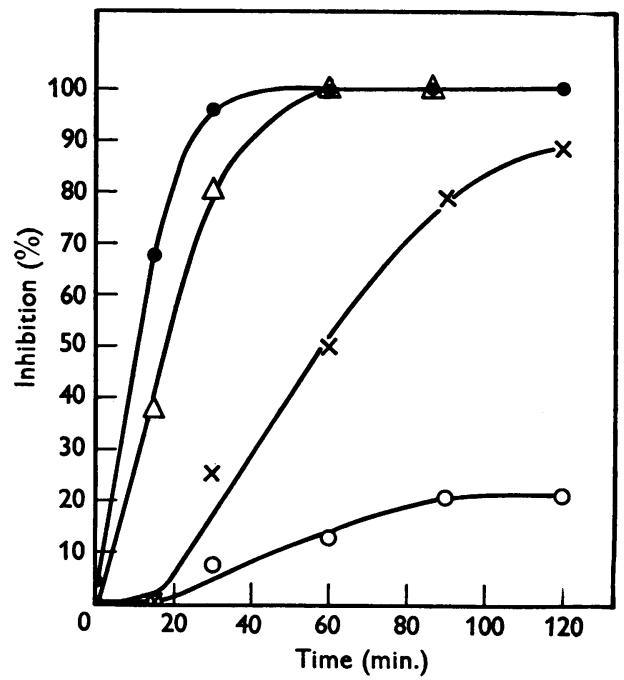

Fig. 3. Irreversible inhibition of glucuronidase after varying periods of contact with Teepol XL at room temperature. Teepol added in concentrations shown to a preparation of acetate-soluble enzyme. Samples transferred at each time interval to assay tubes containing excess inactive protein. $\bigcirc-O, 0.5 \%$ Teepol; $x-x, 0.55 \%$ Teepol; $\bigcirc-$ $0.60 \%$ Teepol; $\triangle-\triangle, 0.5 \%$ Teepol with enzyme diluted to $75 \%$ of its former concentration.

irreversible inactivation of glucuronidase took place depended upon the relative concentrations of enzyme and Teepol. A decrease in the former accelerated inactivation in the same way as an increase in the latter. Inactivation of the enzyme was probably a result of denaturation similar to that described for other proteins treated with ionic surface-active agents (Putnam, 1948).

The question arose whether the inhibition of glucuronidase by Teepol shown in Fig. 2 and Table 6 was entirely due to progressive denaturation of the enzyme during the incubation with substrate, or whether in addition to denaturation there was immediate reversible inhibition of the enzyme by the surface-active agent. To answer this question, velocity curves for the hydrolysis of phenolphthalein glucuronide were drawn up as shown in Fig. 4. Samples were withdrawn for the measurement of free phenolphthalein at $15 \mathrm{~min}$. intervals after the addition of acetate-soluble enzyme to various incubation mixtures.

In each of the two experiments ( $a$ and $b$ in Fig. 4), five flasks were set up containing phenolphthalein glucuronide in acetate buffer, pH 5.2. In four flasks the required amount of Teepol was incorporated in the buffer, and to three of these excess inactive protein (boiled homogenate) was added at 0 ,
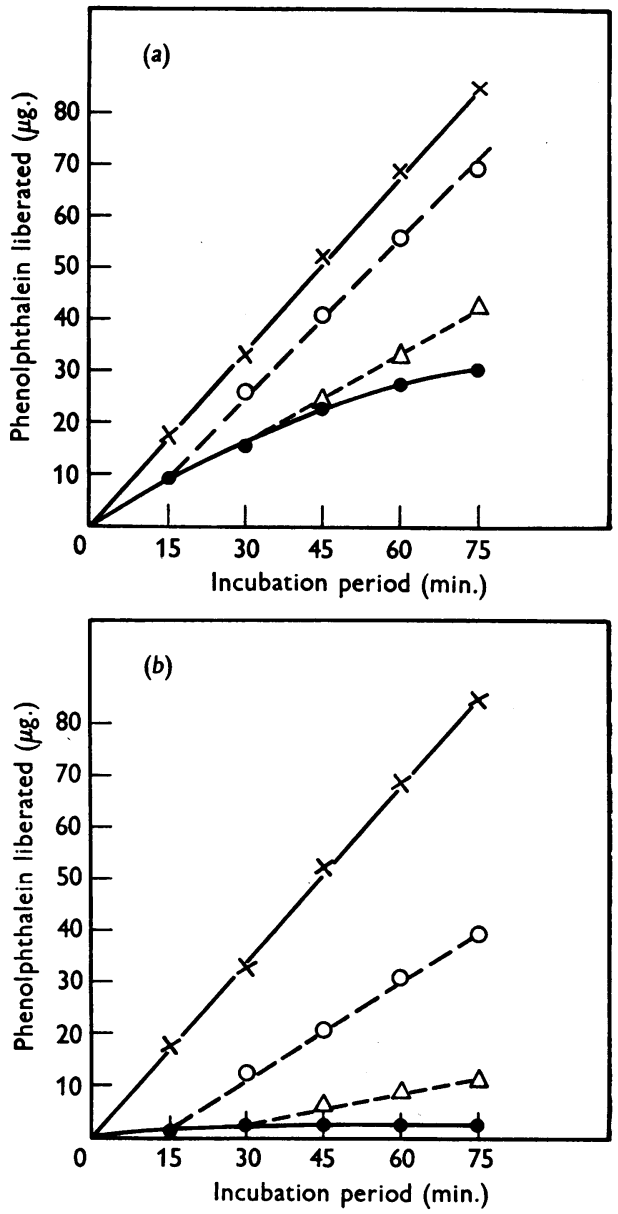

Fig. 4. The rate of hydrolysis of phenolphthalein glucuronide by glucuronidase in the presence of $(a) 0.1 \%$ and (b) $0.12 \%$ Teepol $\mathrm{XL}$, and the effect of adding excess inactive protein. $\times-\times$, control (flask 1); -0 , Teepol alone (flask 2); $\mathrm{O}---\mathrm{O}$, Teepol, with addition of inactive protein after $15 \mathrm{~min}$. incubation (flask 4); $\triangle---\triangle$, Teepol, with addition of protein after $30 \mathrm{~min}$. (flask 5).

15 and $30 \mathrm{~min}$. after the enzyme, respectively. In the other two flasks, inactive protein was replaced by an equal volume of water added with the enzyme. The contents of the flasks may be summarized as follows:

(1) Enzyme + substrate + buffer + water.

(2) Enzyme + substrate + buffer + Teepol + water.

(3) Enzyme + substrate + buffer + Teepol + inactive protein at $0 \mathrm{~min}$. 
(4) Enzyme + substrate + buffer + Teepol + inactive protein at $15 \mathrm{~min}$.

(5) Enzyme + substrate + buffer + Teepol + inactive protein at $30 \mathrm{~min}$.

The rate of hydrolysis after any time interval is given in Fig. 4 by the slope of the line or of the tangent to the curve at that point. In both experiments, the results for flask 3 , in which the enzyme was protected against Teepol from the start, were identical with those for the control (flask 1), and are not shown. In absence of added protein, Teepol (flask 2) caused a progressive falling off in the rate of hydrolysis, which rapidly reached zero in $0.12 \%$ Teepol (Fig. 4b). Addition of inactive protein after 15 or $30 \mathrm{~min}$. (flasks 4 and 5) not only arrested denaturation, but caused an increase in the rate of hydrolysis in both experiments, showing that inhibition of glucuronidase by Teepol is indeed partly reversible. Protein caused a smaller increase in reaction velocity after 30 than after $15 \mathrm{~min}$., indicating that denaturation advanced at the expense of reversible inhibition, and was probably a further stage in the same process.

In addition to the effects already described, Teepol $\mathrm{XL}$ in low concentration precipitated inactive protein from preparations of the acetate-soluble enzyme at $\mathrm{pH} 5 \cdot 2$. With increasing concentration of the surface-active agent, the precipitate started to redissolve, and this point was reached before any change in the activity of the enzyme became evident. No precipitation of active protein was observed at any Teepol concentration under these conditions. Precipitation of a protein by a given ionic surfaceactive agent depends upon the $\mathrm{pH}$ of the medium and the isoelectric point of the protein (Putnam, 1948).

The complete recovery of glucuronidase activity caused by immediate addition of inactive protein to enzyme preparations inhibited by Teepol supports the view that the initial interaction between ionic surface-active agents and proteins in general, as distinct from the subsequent denaturation, is fully reversible (Putnam, 1948).

\section{DISCUSSION}

It is now clear that the fractionation of glucuronidase activity produced in water homogenates of mouse liver by buffering to a slightly acid pH (Kerr \& Levvy, 1951) corresponds to a real difference in the location of the two fractions in the untreated homogenate. This has been demonstrated with the aid of the microscope and the high-speed centrifuge. One fraction appeared to be in true solution whilst the other was associated with the cytoplasmic granules. The ready sedimentation of the latter enzyme fraction observed in buffered preparations was due to agglutination of the granules. Agglutination by acetate buffer was analysed into two components, the effect of $\mathrm{pH}$ and the effect of the electrolyte concen- tration. The former factor was the more important for complete agglutination, but a relatively high electrolyte concentration was required to prevent partial precipitation of the soluble enzyme in the $\mathrm{pH}$ region for agglutination. Glucuronidase activity was found in granules of all sizes. This was in contrast to succinic oxidase activity, which is shown by only the larger granules in tissue homogenates (Schneider \& Hogeboom, 1950). With this complex enzyme system only comparatively large particles can be expected to contain all the essential components. This consideration does not apply to a simple hydrolytic enzyme such as glucuronidase. However, the use of water as the homogenizing fluid caused pronounced osmotic swelling of the nuclei and other cell particles, leading sometimes to disruption. The use of a fluid which tends to preserve these bodies, such as isotonic sodium chloride solution, may be expected to lead to quite a different fractionation of glucuronidase activity on centrifuging the homogenate. This point is at present under investigation.

The conversion of the granular enzyme into a soluble form observed when the homogenate was incubated in acetate buffer (Kerr \& Levvy, 1951) was not a simple autolytic process, but appeared to be fairly specific for acetate ion. Microscopic studies suggested that the enzyme was extracted from the granules during the incubation in acetate. Of other methods for bringing this enzyme fraction into solution, shaking with Ballotini and freezing and thawing caused disintegration of the granules. The action of acetone suggested that the granules are normally surrounded by a protective fatty layer, removal of which permits the escape of water-soluble protein. The non-ionic surface-active agent, Triton $\mathrm{X}-100$, may have acted like acetone in this respect, and the anionic Teepol XL may have produced its effect in the same way or by direct combination with protein. It is tentatively suggested that acetate behaved as a feeble surface-active agent in causing release of the granular enzyme.

Inhibition of glucuronidase by Teepol XL, but not by Triton $\mathrm{X}-100$, is in accordance with the general finding that ionic surface-active agents react with proteins whilst non-ionic do not. It is interesting to contrast the reaction of this simple enzyme towards agents of this type with that of liver succinic oxidase which is inhibited by both ionic and non-ionic surface-active agents (Hockenhull, 1948). It is reasonable to suppose that dispersion of the individual components of a complex system by a non-ionic agent could itself lead to inhibition.

\section{SUMMARY}

1. About $40 \%$ of the glucuronidase activity in a water homogenate of adult mouse liver was sedimented by centrifuging at $25,000 \mathrm{~g}$ for $15 \mathrm{~min}$. This corresponded to the removal from suspension of 
almost all the cytoplasmic granules visible under the phase microscope. Glucuronidase activity was distributed over granules of all sizes.

2. Making the preparation $0 \cdot 1 \mathrm{M}$ with respect to sodium chloride led to slight agglutination and much easier sedimentation of the granules and the associated enzyme activity.

3. Buffering the preparation to $\mathrm{pH} \mathrm{4-6}$ with acetate led to pronounced agglutination of the granules, which then sedimented after $15 \mathrm{~min}$. at $1500 \mathrm{~g}$. Adjusting the $\mathrm{pH}$ to within these limits with acid alone led not only to agglutination of the granules, but.to precipitation of part of the watersoluble enzyme. The latter effect was overcome by adding electrolyte, as in buffered preparations, or by warming.

4. Incubation in acetate buffer, $\mathrm{pH} 5 \cdot 2$, led to extraction of the enzyme from the granules. This did not occur on incubating an untreated homogenate, or after $\mathrm{pH}$ adjustment with acid alone.

5. Shaking a homogenate in a tissue disintegrator, or repeated freezing and thawing, caused disintegra- tion of the granules and release of the associated enzyme to the solution. Homogenizing the tissue in acetone followed by resuspension in water had the same effect, but release of the enzyme was not seen when the acetone-dried powder was resuspended in acetate buffer.

6. Treatment with the surface-active agents, Teepol XL and Triton X-100, brought the granular enzyme into solution with disappearance of particulate matter from the preparation.

7. Glucuronidase was inhibited non-competitively by the anionic Teepol XL, but not by the non-ionic Triton X-100. Inhibition by Teepol was at first reversed by adding inactive protein, but later became irreversible.

The authors wish to express their gratitude to their colleague, Mr F. Baker, for instruction in the use of the phase microscope, and to the Rohm and Haas Company for gifts of Triton A-20 and X-100. Contact with this firm was made through the courtesy of Dr H. N. Glassman. One of us (P.G.W.) is in receipt of a grant from the Agricultural Research Council.

\title{
REFERENCES
}

Dalton, A. H., Kahler, H., Kelly, M. G., Lloyd, B. J. \& Striebich, M. J. (1949). J. Nat. Cancer Inst. 9, 439.

Discombe, G. (1950). Acta Haematologica, 3, 151.

Fishman, W. H. (1939). J. biol. Chem. 127, 367.

Fishman, W. H., Springer, B. \& Brunetti, R. (1948). J. biol. Chem. 173, 449.

Glassman, H. N. (1950). Science, 111, 688.

Graham, A. F. (1946). Biochem. J. 40, 603.

Hockenhull, D. (1948). Nature, Lond., 162, 850.

Kerr, L. M. H., Campbell, J. G. \& Levvy, G. A. (1949). Biochem. J. 44, 487.
Kerr, L. M. H. \& Levvy, G. A. (1951). Biochem. J. 48, 209. Levvy, G. A., Kerr, L. M. H. \& Campbell, J. G. (1948). Biochem. J. 42, 462.

Mickle, H. (1948). J. R. micr. Soc. 68, 10.

Opie, E. L. (1949). J. exp. Med. 87, 440.

Putnam, F. W. (1948). Advanc. Prot. Chem. 4, 79.

Rabinovitz, M. \& Boyer, P. D. (1950). J. biol. Chem. 183, 111.

Schneider, W. C. \& Hogeboom, G. H. (1950). J. biol. Chem. $183,123$.

Zollinger, H. (1948). Amer. J. Path. 24, 569.

\section{Degradative Studies on the 'Core' Resulting from Chymotryptic Digestion of Insulin}

\author{
BY JOAN M. L. STEPHEN \\ The Courtauld Institute of Biochemistry, Middlesex Hospital Medical School, London, W. 1
}

\section{(Received 23 January 1951)}

Previous work on the action of enzymes on insulin (Butler, Dodds, Phillips \& Stephen, 1948) has shown that chymotryptic digestion releases a number of peptide fragments which are soluble in $0.25 \mathrm{~N}$ trichloroacetic acid, leaving a 'core', with a molecular weight of approximately 5000 , which is precipitated, Some properties of this core have already been described (Butler, Phillips, Stephen \& Creeth, 1950).

The core can be oxidized by the method used by Sanger $(1949 a)$ for insulin, but application of
Sanger's fractionation procedure did not separate the glycyl and phenylalanyl chains as in the original insulin. Difference in solubility at $\mathrm{pH} 6 \cdot 5$, which in oxidized insulin distinguishes the chains, does not occur among the oxidation products of the core, presumably because of the decreased length of the chains and the removal from the phenylalanyl chains of a large proportion of the basic amino-acids by enzymic action.

The oxidation products of the dinitrophenyl derivative of the core or the dinitrophenyl or benzoyl 